\title{
Introduction: EU constraints and opportunities in the COVID-19 pandemic - the politics of NGEU
}

\author{
Caroline de la Porte ${ }^{1} \cdot$ Elke Heins $^{2}$
}

Accepted: 30 January 2022 / Published online: 7 March 2022

(C) The Author(s), under exclusive licence to Springer Nature Limited 2022

\begin{abstract}
This Special Issue focuses on how EU politics, policies and institutions, all nested in the past, have a bearing on welfare states in the context of the ongoing COVID-19 pandemic. In this introductory article, we first provide a brief overview of the growing scholarship on the impact of the pandemic on both national welfare systems and EU policies. We then contextualise the initial pandemic policy responses by highlighting the economic challenges to European welfare states leftover from the Great Recession and Eurozone crisis before outlining the timeline of the EU reaction to the COVID-19 crisis, culminating in the Next Generation EU deal. Finally, we summarize the distinctive empirical and theoretical perspectives of each contribution to this Special Issue. Taken together, the articles in this issue offer a much-needed analysis of the interplay between EU level and member state politics that furthers our understanding of the social and economic policies implemented in the first year of the COVID-19 pandemic in Europe.
\end{abstract}

Keywords COVID-19 · EU integration · Economic governance · NGEU · Welfare states

\section{Introduction}

This Special Issue builds on the emerging scholarship on national and EU responses to the COVID-19 pandemic. National political responses have posed challenges to democracy and to democratic institutions (Goetz and Martinsen 2021), while the economic effect of the COVID-19 pandemic has, at least partially, been cushioned

Caroline de la Porte

cdlp.egb@cbs.dk

Elke Heins

elke.heins@ed.ac.uk

1 Department of International Economics, Government and Business, Copenhagen Business School, Frederiksberg, Denmark

2 University of Edinburgh, Edinburgh, UK 
by Europe's welfare states. At the same time, the pandemic has also led to changes in labour markets and welfare systems (Béland et al 2021; Pereirinha and Pereira 2021; Seemann et al 2021). The EU level response, after an initial lag, showed that the heads of state and government, despite different political interests, were able to reach an agreement on a common EU fund, Next Generation EU (NGEU), intended to support member states in shifting to a digitalized and green growth model (de la Porte and Jensen 2021; Ladi and Tsarouhas 2020, Schmidt 2021). There were also various sector-specific responses, e.g. regarding climate or health policy, which have been remarkable in their own right (Dupont et al 2020; Brooks and Geyer 2020). Furthermore, the coordination of vaccine purchases is an undervalued success of the EU response (Rhodes 2021). Yet, the EMU response has been characterised as 'failing forward' in the framework of the pre-existing institutional structure (Howarth and Quaglia 2021).

The red thread of our special issue, connecting the EU and national levels of governance, focuses on how EU politics, policies and institutions, all nested in the past, have a bearing on national welfare states and EU-wide social policy coordination in the context of the COVID-19 pandemic. The articles explicitly take into account that this most recent crisis plays out against the back-drop of EU austerity in response to the European sovereign debt crisis, which prompted an alteration of the EU's economic governance structure (de la Porte and Heins 2015). The imposition of conditions on individual countries in MoUs and the strengthened EMU governance regime led to reforms in labour markets and welfare states, through explicit and implicit conditionality (Dukelow 2015; Erne 2015; Hassenteufel and Palier 2015; Pavolini et al 2015; Sacchi 2015). As a consequence, labour unions were weakened (Jordan et al 2021; Rathgeb and Tassinari 2020;) and public support for the EU decreased dramatically (Armingeon and Cranmer 2018). A decade later, at the outbreak of the pandemic, public support for the EU had recovered, but was fragile. The remainder of this introduction presents the stages of the EU response to the crisis, culminating in the NGEU. Then, it summarizes the distinctive empirical and theoretical perspective of each contribution to the special issue.

\section{Towards the NGEU}

The economic crisis that started in 2020 as a consequence of the first round of nationwide lockdowns made it difficult to respect the budgetary requirements of the EMU. As a left-over from the Great Recession, some countries had already been struggling with high accumulated public debt, especially Greece and Italy, while several further countries had difficulty keeping their yearly expenditure at bay, i.e. France and Spain. Furthermore, unemployment rates were high in Greece and Spain even before the start of the pandemic (see Table 1 below).

Given the pandemic situation and the necessity to enforce lockdowns, most EU countries introduced income replacement and/or short-term work schemes as well as a range of other social policy measures to support the population in adaption to the disruptions of work and family lives, leading to high budget deficits (Eichhorst et al 2020; Pereirinha and Pereira 2021; Seemann et al 2021). Thus, the first major 
Table 1 Public deficit, public debt and unemployment rates in selected countries, 2010-2919

\begin{tabular}{|c|c|c|c|c|c|c|c|c|c|}
\hline & \multicolumn{3}{|c|}{ General gov’t debt (gross) } & \multicolumn{3}{|c|}{ General gov't deficit (gross) } & \multicolumn{3}{|c|}{ Unemployment rate } \\
\hline & 2010 & 2015 & 2019 & 2010 & 2015 & 2019 & 2010 & 2015 & 2019 \\
\hline France & 85.3 & 95.6 & 98.1 & -6.9 & -3.6 & -3.0 & 9.3 & 10.4 & 8.5 \\
\hline Germany & 82.3 & 72.3 & 59.6 & -4.4 & 1.0 & 1.5 & 7.0 & 4.6 & 3.1 \\
\hline Greece & 147.5 & 177.0 & 180.5 & -11.3 & -5.7 & 1.5 & 12.7 & 24.9 & 17.3 \\
\hline Italy & 119.2 & 135.3 & 134.7 & -4.2 & -2.6 & -1.6 & 8.4 & 11.9 & 10.0 \\
\hline Spain & 60.5 & 99.3 & 95.5 & -9.5 & -5.2 & -2.9 & 19.9 & 22.1 & 14.1 \\
\hline
\end{tabular}

Source Eurostat

initiative of the European Commission in the context of the COVID-19 crisis, on $20 \mathrm{March}$, was to propose the activation of the general escape clause of the Stability and Growth Pact (SGP). On 23 March, the Council of Economic and Financial Affairs fully supported this proposal (Council of the EU 2020). The general escape clause does not suspend the procedures of the SGP, but it allows the Commission and the Council to undertake the necessary policy coordination measures within the framework of the SGP, while allowing for deviation from the budgetary requirements (European Commission 2020a; Council of the EU 2020). This issue was not contentious, since all member states had seen their public budget deficits increase due to extraordinary COVID-related expenditure. Importantly, whereas the previous European sovereign debt crisis could partly be attributed to the imbalances with the EMU but also partly to endogenous factors, thus leading to moral hazard accusations, the economic shock of the COVID-19 crisis is clearly of exogenous nature and its cause indisputably outside the control of government. However, this decision could worsen the long-term problem of accumulated debt, which remains a major challenge in some countries, including Greece, Italy, Spain and France (see Table 1). Two years on, at the time of writing, the SGP is still suspended, and discussions on the future reforms of the SGP are on-going.

Following this, the second milestone was the agreement by the Eurogroup on 9th April 2020 on a 'corona package' of up to 540 billion euros. Of this, 240 billion euros would be available under the European Stability Mechanism (ESM) for Eurozone members. Each Eurozone country would be allowed to borrow up to $2 \%$ of GNI for reform measures related to the economic effects of the pandemic. In addition, two other instruments were also agreed by the Eurogroup. The first comprised loans for investments under the European Investment Bank (EIB, up to 200 billion euros), targeted at hard-hit small and medium-sized enterprises; the second was a new scheme called 'Support to mitigate Unemployment Risks in an Emergency' (SURE, up to 100 billion euros) which co-finances the creation or extension of national short-time work schemes and similar measures for the self-employed with the aim of preventing or at least delaying unemployment (European Commission 2020b).

Due to the exogenous shock character of the pandemic, and against the back-drop of negative public opinion towards the EU following the austerity years (Armingeon 
and Baccaro 2012; Armingeon and Cranmer 2018), the idea of adopting an EU instrument to alleviate the economic and social consequences of COVID-19 was widely supported by member states. A breakthrough towards a large-scale EU-funding package was achieved when France and Germany on 18 May 2020 launched the idea of a European fund to respond to the health and economic crisis (Bundesregierung 2020). The proposal put forward a $€ 500$ billion fund in grants, to be disbursed to regions and sectors adversely affected economically by the pandemic. This agreement was a way to demonstrate political leadership in the EU, to revive the Franco-German alliance, and to signal their own political priorities, ahead of the Commission Communication (European Commission 2020a).

The next major step was a proposal tabled by the European Commission on 27 May, comprising a $€ 750$ billion fund, of which 500 billion euros were proposed as grants, and 250 billion euros as loans. In advance of the European Council meeting, the four 'Frugals' (Denmark, Sweden, Austria and the Netherlands) presented their joint position, supporting loans, rather than grants (Frugals non-paper 2020). Italy and Spain, in contrast, argued that the recovery fund should be made up of grants, with virtually no conditionality for the disbursement of grants. The 'Frugals'-Southern Europe divide reflects the more general divide between creditor and debtor countries in the EU, which continues to swelter under the surface. Despite these differences among member states, the European Council agreed on the NGEU and on the MFF for 2021-2027 in its extraordinary meeting concluded on 21st July 2020 (European Council 2020). It was later approved by the European Parliament, after unspent funds from the previous budget were added to the NGEU (de la Porte and Jensen 2021).

In November 2020, however, Hungary and Poland vetoed the long-term EU budget and NGEU package, due to their objection against the Commission proposal to tie funds to the rule-of-law principle. Eventually, the directive to strengthen ruleof-law compliance was watered down to get Hungary and Poland on board, and in December 2020, the long-term budget and NGEU were adopted by the Council. While the NGEU is historic, the political tensions around rule-of law conditionality as well as between debtor and creditor countries prevail (Fig. 1).

\section{The contributions}

The articles in this special issue cast light on the politics and policies of EU-national social and fiscal integration initiated by the COVID-19 pandemic. At the time of writing, the pandemic was far from over: new variants of the virus emerged and further restrictions to work and socialising remained a continuous prospect. Our focus is therefore on the policy responses to the first and second waves of the pandemic in 2020. Despite the unfinished character of the crisis and therefore the difficulty of 'hitting a moving target', important developments both within member states and at EU level have been occurring throughout 2020 that deserve a systematic analysis.

Our selection of papers has been guided by four inter-related, yet distinct cleavages regarding EU social integration identified by Ferrera (2017) that had an influence on the decision-making process towards NGEU at both European and member 


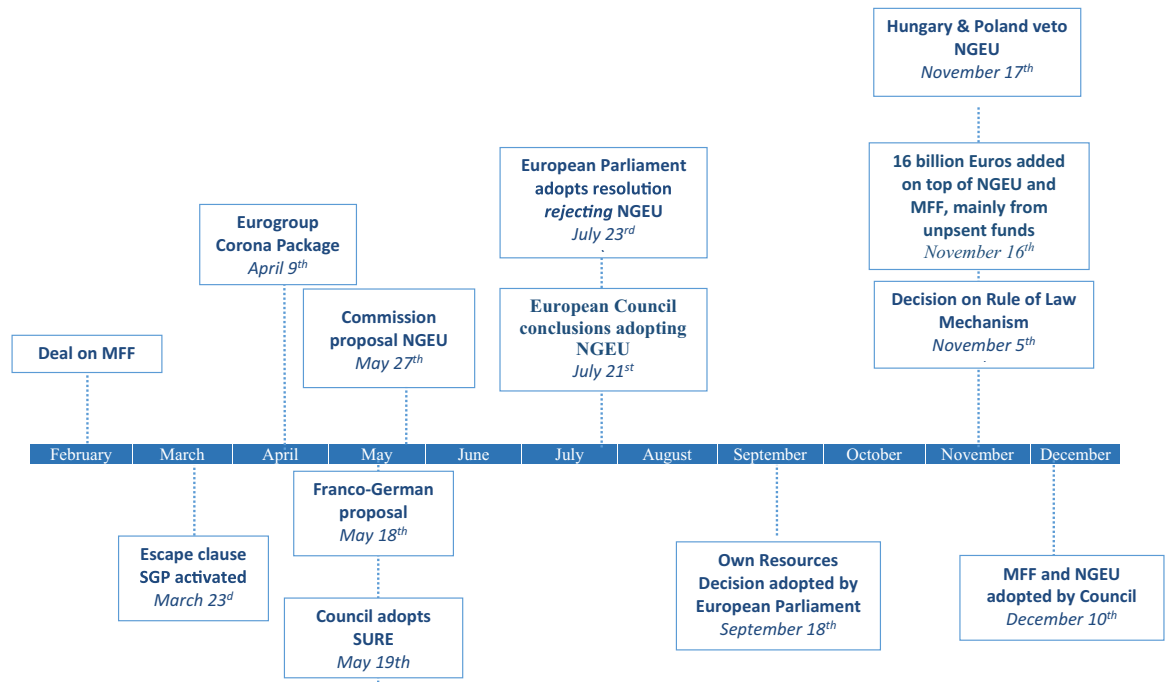

Fig. 1 Main steps of the EU's fiscal response to the COVID-19 pandemic Source: authors' own creation, on the bais of main events

state level: first, there are continuing ideological divides between the political left and right over 'market-making' versus 'market-correcting' priorities. The second is a 'pro versus contra European integration' divide determining views on national sovereignty on social matters versus a binding EU interference in welfare states and national labour markets. Third, a previously more latent, but since the sovereign debt crisis manifest tension has emerged between so-called 'creditor' and 'debtor' countries. A fourth is linked to free movement, access to national welfare states and 'social dumping'. While the third cleavage broadly speaking differentiates Northern and Southern Member States, the fourth is linked to Eastern enlargement, territorially separating 'high wage/high welfare' regimes in the old (Western) Member States from 'low wage/low welfare' regimes in the new (Eastern) Member States.

The first article, 'Voices from the Past: Economic and Political Vulnerabilities in the Making of Next Generation EU', which we have co-authored with Klaus Armingeon and Stefano Sacchi, characterizes Next Generation EU (NGEU) as a pre-emptive intervention to avoid the high political and economic costs associated with the EU response to the sovereign debt crisis. Conceptually, the paper builds on economic and political vulnerabilities, where the former is a measure of macro-economic (in)stability, while the latter is a measure of public support for the EU. In a first part, the paper demonstrates that pre-existing economic and political vulnerabilities, rather than the impact of the pandemic, drove the allocation of NGEU resources. This signifies that countries most vulnerable to another adjustment by austerity and countries with strong anti-EU sentiments are entitled to larger NGEU grants per capita than countries that are macro-economically more stable and less Eurosceptic. In a second part, three case studies demonstrate the significance of economic interests and political polarization in national positions on NGEU in 
countries representing different interests with regard to an EU fiscal instrument: Italy, Germany and the Netherlands. We conclude that despite its innovative traits, NGEU is a politically constrained solution to address the mess leftover from the previous decade, and as such, it is a Janus solution: promising a fresh start, but haunted by the past.

In the article 'Germany, the Eurozone crisis and the COVID-19 pandemic: failing forward or moving on?', Simon Bulmer explores continuity and change in Germany's policy towards economic and monetary integration since the COVID-19 pandemic. At first sight, the Franco-German proposal for a recovery fund seemed to indicate a clear and sudden break with Germany's traditional stability culture and its aversion to taking on financial liability. However, taking a historical-institutionalist perspective Bulmer argues that Germany's policy stance has incrementally evolved through a layering process rather than a critical juncture or abrupt paradigm change. He concludes that the resultant Recovery and Resilience Facility (RRF) may prove to be another incomplete policy response due to the deepening consequences of the pandemic. The tensions between domestic policy preferences, in the German case additionally constrained by the interventions of the Federal Constitutional Court, and the integration of economic and social policies at European level are thus likely to endure.

In the article 'A more liberal France, a more social Europe? Macron, two-level reformism and the COVID-19 crisis', Daniel Clegg shows how the crisis prompted by the COVID-19 pandemic poses challenges for welfare and labour market reform in France. President Macron was elected in 2017 promising to reform France's social model in the light of the liberalising direction of the Eurozone. Structural reform and budgetary consolidation at home were supposed to increase France's credibility at European level and to act as counterweight to Germany. At the same time, EUlevel influence gained through domestic reforms was meant to be used to strengthen the social dimension of the EU by making the case for changes to orthodox prescriptions for Eurozone austerity and liberalisation. This simultaneous and explicitly linked action in both the domestic and European arenas-two-level reformism-was seen as crucial in generating political support for the 'more liberal France, more social Europe' project. The COVID-19 crisis interfered with these double reform plans that pre-pandemic met with domestic opposition and proved insufficient to significantly enhance France's leverage at EU level. COVID-19 generated some unanticipated momentum for Eurozone reform, but at the same time further complicated both the implementation and the politics of Macron's domestic reform agenda, as the example of unemployment insurance demonstrates.

Sotiria Theodoropoulou argues in her article that despite the more benign intentions of the NGEU and the RRF, Greece is caught 'in-between conditionalities' as the past conditions imposed on Greece for lightening the servicing of the debt from the previous crisis (and therefore, 'previous' conditionality) are likely to constrain the Greek response and planned use of the pandemic recovery funds. At the beginning of the pandemic, Greece had been under 'enhanced surveillance', with its progress in implementing agreed reforms and budget positions being monitored by the 'institutions'. Greece is very much stuck with the unresolved leftovers from the past, which still determine the entire economic 
framework of the country. The substantial grants from the RRF are thus not likely to solve the ongoing challenges of a high public debt burden that Greece is facing.

Similar to Greece, the third and fourth largest economies of the EU-Italy and Spain-are burdened by large public debts, high unemployment (especially Spain) and economies with a large share of SMEs as well as a large service sector. This has made them very vulnerable economically prior to the pandemic, and it helps to explain political vulnerability, i.e. both countries have become more polarized since the 2010s, following austerity measures related to the Great Recession. The contribution by Ana Guilén, Margarita León and Emmanuele Pavolini first presents the legacy of the past in terms of economic and political conditions and characterizes the challenges in reforming their social protection systems. It then shows that the RRF plans could be leading to a more pronounced social investment turn of the southern welfare states in healthcare, education, ALMPs, housing and other forms of social inclusion and growth promotion. Thus, the RRF presents long-awaited means-a 'carrot' rather than a conditionality 'stick' - to deal with the country-specific recommendations in social protection. Whether the national plans deliver and lead to a convergence of the Italian and Spanish towards a social investment welfare state remains to be seen.

Finally, the tensions between the high wage/high welfare countries in the core and low wage/low welfare countries in the periphery play out in the context of rapidly changing labour markets-exacerbated by the pandemic-where automation and digitalization create new polarizations between high-skilled workers who can work from home and are protected by social security systems and lowskilled workers, many of them now termed 'essential', who face multiple precarities, including exposure to the virus while working in social or healthcare, delivery, transport and logistics or as seasonal workers. This is not only a newly arising tension within welfare states, but also plays out on the European level as workers from eastern Europe, undertaking low-paid low-skilled jobs that benefit northern Europe, are putting their own health at risk. Longstanding migration patterns from new member states to older member states thus gain a new significance in the lights of a pandemic as Dorota Szelewa and Michal Polakowski demonstrate in their contribution titled 'European solidarity and "free movement of labour" during the pandemic: exposing the contradictions amid East-West migration'. They focus on EU-level responses as well as on the reactions in Germany and the UK to the COVID-19 crisis in relation to labour shortages in the food sector. Labour shortages in this particular sector constituted an emergency situation for food producers and consumers when it became clear that food supply chains in several Western European countries would fall apart without Eastern European workers. The situation has brought to light pre-existing issues pertaining to working conditions, including housing and sanitation, which have suddenly become more salient due to the health risks to employees and the public. While in both countries, an emphasis was placed on the specific suitability of Eastern European workers for jobs in the food industry, the paper shows that the discourse in Germany was much more focussed on the issues of working conditions and health risks, with general reference to the EU context. In contrast, the dominant 
narrative in the UK was about the sustainability of production and perseverance of the 'British' food industry.

The articles forming this special issue thereby shed much-needed light on the interplay between the European Union level and domestic politics when analysing the policy responses to the COVID-19 pandemic in its initial stages. While the wide geographical coverage of the papers in their entirety provides empirical breadth, the various angles and specific questions posed by the individual articles also offer valuable theoretical-conceptual contributions to the scholarly debate that, two years into the outbreak of the pandemic, is likely to continue for the foreseeable future. Most notably, it remains to be seen whether NGEU, together with the European Pillar of Social Rights, can help resolve some of the underlying cleavages of EU integration addressed in this issue and will lead to a fundamental change in European economic and social governance.

\section{References}

Armingeon, K., and S. Cranmer. 2018. Position-taking in the Euro Crisis. Journal of European Public Policy 25 (4): 546-566.

Armingeon, K. and L. Baccaro (2012) The sorrows of young Euro: Policy responses to the sovereign debt crisis. In Coping with crisis: Government reactions to the great recession, ed. Bermeo N. and J. Pontusson,162-197.

Brooks, E., and R. Geyer. 2020. The development of EU health policy and the Covid-19 pandemic: Trends and implications. Journal of European Integration 42 (8): 1057-1076.

Bundesregierung P.U.I. 2020. A french-german initiative for the European recovery from the coronavirus crisis. Nr. 173/20, 18 May. https://www.bundesregierung.de/breg-de/suche/deutschfranzoesische-initiative-zur-wirtschaftlichen-erholung-europas-nach-der-coronakrise-17537 60. Accessed 18 Mar 2021.

Béland, D., B. Cantillon, R. Hick, and A. Moreira. 2021. Social policy in the face of a global pandemic: Policy responses to the COVID-19 Crisis. Social Policy \& Administration 55 (2): 249-260.

Dukelow, F. 2015. Pushing against an open door: Reinforcing the neo-liberal policy paradigm in ireland and the Impact of EU Intrusion. Comparative European Politics 13 (1): 93-111.

Dupont, C., S. Oberthür, and I. von Homeyer. 2020. The Covid-19 crisis: A critical juncture for EU climate policy development? Journal of European Integration 42 (8): 1095-1110.

Eichhorst, W., P. Marx, and U. Rinne. 2020. Manoeuvring through the crisis: Labour market and social policies during the Covid-19 pandemic. IZA policy paper no. 164. Bonn: Institute for Labour Economics.

Erne, R. 2015. A supranational regime that nationalizes social conflict: Explaining European trade unions' difficulties in politicizing European economic governance. Labor History 56 (3): 345-368.

European Commission. 2020a. Europe's moment: Repair and prepare for the next generation, 27 May 2020a, COM/2020b/456 final.

European Commission. 2020b Proposal for a Council Regulation on the establishment of a European instrument for temporary support to mitigate unemployment risks in an emergency (SURE) following the COVID-19 outbreak, 2 April 2020b, COM (2020b), 139 final.

European Council. 2020. Conclusions of the European Council meeting 17-21 July, Brussels. https://www.consilium.europa.eu/media/45109/210720-euco-final-conclusions-en. pdf, Accessed 5 May 2021.

Ferrera, M. 2017. The stein rokkan lecture 2016: Mission impossible? Reconciling economic and social Europe after the Euro Crisis and Brexit. European Journal of Political Research 5 (6): 3-22.

Frugals non-paper. 2020. EU support for efficient and sustainable COVID-19 recovery. Amsterdam: Rijksoverheid. https://www.rijksoverheid.nl/documenten/publicaties/2020/05/26/non-papereu-support-for-efficient-and-sustainable-covid-19-recovery. Accessed 3 Jan 2022. 
Goetz, K.H., and D.S. Martinsen. 2021. COVID-19: A dual challenge to European liberal democracy. West European Politics 44 (5-6): 1003-1024.

Hassenteufel, P., and B. Palier. 2015. Still the sound of silence? Towards a new phase in the Europeanisation of welfare state policies in France. Comparative European Politics 13 (1): 112-130.

Howarth, D., and L. Quaglia. 2021. Failing forward in economic and monetary union: Explaining weak Eurozone financial support mechanisms. Journal of European Public Policy 28 (10): 1555-1572.

Johnston, A., and A. Regan. 2016. European monetary integration and the incompatibility of national varieties of capitalism. JCMS Journal of Common Market Studies 54 (2): 318-336.

Jordan, J., V. Maccarrone, and R. Erne. 2021. Towards a socialization of the EU's economic governance regime? EU labour policy interventions in Germany, Ireland, Italy and Romania (2009-2019). British Journal of Industrial Relations 59 (1): 191-213.

Ladi, S., and D. Tsarouhas. 2020. EU economic governance and Covid-19: Policy learning and windows of opportunity. Journal of European Integration 42 (8): 1041-1056.

Pavolini, E., M. León, A.M. Guillén, and U. Ascoli. 2015. From austerity to permanent strain? The EU and welfare state reform in Italy and Spain. Comparative European Politics 13 (1): 56-76.

Pereirinha, J.A.C., and E. Pereira. 2021. Social resilience and welfare systems under COVID-19: A European comparative perspective. Global Social Policy 21 (3): 569-594.

de la Porte, C., and E. Heins. 2015. A new era of European integration? Governance of labour market and social policy since the sovereign debt Crisis. Comparative European Politics 13 (1): 8-28.

de la Porte, C., and M.D. Jensen. 2021. The next Generation EU: An analysis of the dimensions of conflict behind the deal. Social Policy \& Administration 55 (2): 388-402.

Rathgeb, P., and A. Tassinari. 2020. How the Eurozone disempowers trade unions: The political economy of competitive internal devaluation. Socio-Economic Review. https://doi.org/10.1093/ser/mwaa021.

Rhodes, M. 2021. Failing forward: A critique in light of Covid-19. Journal of European Public Policy 28 (10): 1537-1554.

Sacchi, S. 2015. Conditionality by other means: EU involvement in Italy's structural reforms in the Sovereign Debt Crisis. Comparative European Politics 13 (1): 77-92.

Schmidt, V.A. 2020. Theorizing institutional change and governance in European responses to the Covid19 pandemic. Journal of European Integration 42 (8): 1177-1193.

Seemann, A., U. Becker, L. He, E.M. Hohnerlein, and N. Wilman. 2021. Protecting livelihoods in the COVID-19 crisis: A comparative analysis of European labour market and social policies. Global Social Policy 21 (3): 550-568.

Wolff, S., and S. Ladi. 2020. European Union responses to the Covid-19 pandemic: Adaptability in times of permanent emergency". Journal of European Integration 42 (8): 1025-1040.

Publisher's Note Springer Nature remains neutral with regard to jurisdictional claims in published maps and institutional affiliations. 